\title{
Scientific Literacy For All
}

\author{
Halil TURGUT ${ }^{1}$
}

\begin{abstract}
Projects that developed for solving problems faced within education systems of countries seemed to get great attention day to day. The motivation of reform projects can be shown as the most concrete sample for that. Within this context one of the most popular concepts of current reform movements is seen to be scientific literacy. However, altough scientific literacy is used since 1950 's and accepted by nearly everyone, a consensus on scientific literacy can not be claimed. In this research by paying attention to this issue, it is aimed to examine the history of scientific literacy, to view the definitions of different researchers, to determine its subdimensions and to discuss if scientific literacy should be a goal for all. For this, a widespread search is done and scientific liretacy is tried to be shown as a goal for all within the general education perspective.
\end{abstract}

Keywords: Scientific Literacy, Nature of Science, ScienceTechnology-Society

\section{SUMMARY}

Scientific liretacy has been one of the most important issues of science education because of its central role in recent educational reform movements nowadays. But with this great emphasis on scientific literacy, the meaning of the term, its subdimensions, the reasons for its importance, the ways of

${ }^{1}$ Dr., Marmara University, Atatürk Faculty of Education 
measuring it and the target population are still a bit fuzzy. The statements of Matthews (1994) that scientific literacy has no one correct definition and Laugksch (2000) that this is because of interrelations between interest groups, conceptual definitions, nature of concept, ways of measuring and reasons of being favour of scientific literacy can be given as strict examples for this view. For that reason scientific literacy is now at the focus of discussions. So, defining scientific literacy in the light of recent definitions of researchers, researcher groups and institutions and determining its subdimensions for grounding it in educational settings is important.

In this research with this motivation, scientific literacy was examined in a widespread manner in its historical context and questioned if scientific literacy can be a goal for all within the general education perspective. The research was conducted as a historical research for reasons Bybee (1982) mentioned and literature was scanned in the light of criterions determined by him as importance and relatedness because of the huge literature faced. The journal writings, books and presented papers taken into consideration primarily and the writings of DeBoer (2000), Laugksch (2000), Shamos (1995) and Hurd (1958) were the sources most used.

Within the research design firstly the historical development process of scientific literacy was viewed and the conceptual definitions developed by researhers and institutions were examined. By research done it was seen that scientific literacy is a concept that had been used since 1950's and although he did not explore, after firstly pronounced by Hurd (1958) it became one of the most important theme of science education. The related literature showed that the domain and emphasis of scientific literacy had changed within its developmet period since 1950's.

By 1960's, after Soviet Union launched the satellite Sputnik, science education community in USA tended to focus more on the strategic role of scientific knowledge in society. Within this period the increased interest in academic disciplines became to be the main concern in science education. But after 1960's, the focus on scientific content knowledge tended to disappear and by 1970's science educators started to discuss if focusing on the process and structure of science without paying attention to the interests and developmental needs of students was a correct choice.

This shift became more appearent after 1970's and scientific literacy tended to be defined more in social context of science. Gallagher (1971: 337) stated the need for citizens of modern society to understand also sciencesociety-technology interaction with scientific concepts and processes, Hurd (1970, Akt. DeBoer, 2000: 588) proposed social context of science as the most appropriate context of science education under general education. The meanings assigned to scientific literacy in recent educational reform 
movements and studies such as Project 2061, Science-Technology-Society, National Science Education Standarts etc. and by researchers are also given in this context.

In this research, in the light of historical development process of scientific literacy and definitions developed within that process, subdimensions of scientific literacy were also aimed to be determined. It was seen that the most common subdimensions within definitions reached in literature were nature of science, science-technology-society interaction and scientific knowledge-terminology. These subdimensions determined were also in congruence with those offered by Miller (1983) and examined individually for what they mean and how they are a part of scientific literacy.

The scientific knowledge-terminology is seen to be the most known and studied subdimension of scientific literacy but the nature of science and science-technology-society interaction subdimensions of scientific literacy (although took attention in recent reform movements) are not. So in this research, nature of science, science-technology-society interaction took more place. The definitions of nature of science viewed, science-technologysociety interaction interpreted and their meanings for science education discussed.

Lastly, the issue that if scientific literacy can be a goal for all within general education perspective was discussed with the criterion of being realist while defining scientific literacy and proposing qualifications for being scientifically literate. The conclusion arrived was that the scientific literacy can be a goal for all at least at basic level for citizens of modern world. 


\section{Herkes İçin Bilimsel Okuryazarlık}

\section{Halil TURGUT*}

ÖZ: Ülkelerin eğitim sistemlerinde karşılaştıkları sorunlar için çözüm üretme projeleri her geçen gün daha fazla ağırlık kazanmaktadır. Reform hareketlerinde ortaya konulan motivasyon bunun en somut örneğidir. $\mathrm{Bu}$ bağlamda son yılların reform hareketleri incelendiğinde en çok öne çıkan kavramın bilimsel okuryazarlık olduğu görülmektedir. Buna karşın 1950'lerden beri kullanılagelen ve hemen herkes tarafindan kabul gören bilimsel okuryazarlığın zihinlerde ortak bir çağrışımının olmadığını, farklı yaklaşımlarla gündeme taşındığını söylemek mümkündür. $\mathrm{Bu}$ araştırmada da bu hususa dikkat çekerek bilimsel okuryazarlık kavramının tarihi gelişim sürecinin yorumlanması, farklı araştırmacıların açılımlarının incelenmesi, alt boyutlarının belirlenmesi ve herkes için bir hedef olarak sunulup sunulamayacağının tartışılması amaçlanmıştır. Bu amaçla çok yönlü literatür taraması yapılmış ve bilimsel okuryazarlığın genel eğitim perspektifi içerisinde herkes için bir hedef olması gerektiği ortaya konulmaya çalışılmıştır.

Anahtar Kelimeler: Bilimsel Okuryazarlık, Bilimin Doğası, Bilim-Teknoloji-Toplum

\section{GİRIŞ}

Son yılların eğitim reformu hareketlerinin birçoğunda odak bir kavramın temel hedefler arasında vazgeçilmez biçimde yerini aldığ göze

* Dr., Marmara Üniversitesi, Atatürk Eğitim Fakültesi 
çarpmaktadır: bilimsel okuryazarlık. Buna karşın bugünün bu çok popüler kavramının kullanımının yaygınlığı kadar üzerinde yürütülen tartışmaların da ciddi bir hacim oluşturduğunu ifade etmek gerekir. Bilimsel okuryazarlığın üzerinde tam anlamıyla uzlaşılmış bir tanımının olup olmadığının bile tartışıldığı dikkate alınırsa bu iddianın gerçekliği kolayca anlaşılabilir.

Bilimsel okuryazarlık kavramının kökeni iki belki de daha fazla yüzyıl öncesine kadar gitse de kavram bugün telaffuz edildiği şekliyle ilk defa 1950'lilerde kullanılmıştır (Bybee, 1997; DeBoer, 1991). O günlerden bugüne kadar da gittikçe artan bir kabul görerek bir eğitim sloganına dönüşmüştür. Birçok araştırmacı araştırmalarında odak kavram olarak kullanmış, tanımlamaya, farklı açılımlara gitmeye çalışmış, ciddi kurum ve kuruluşlar oluşturdukları geniş katılımlı komisyonlarla kavramı eğitim ortamlarına aktarılabilir hale getirme çabası içinde olmuşlardır. Fakat yine de karşı karşıya bulunulan kavramın herkes için aynı şeyi ifade edip etmediği tartışma konusu olmaya devam etmiştir. Matthews (1994)'in bilimsel okuryazarlığın tek bir doğru tanımının söz konusu olmadığını ifade etmesi ve Laugksch (2000)'un bu durumu ilgi gruplarının, kavramsal açılımların, kavramın doğasının, ölçme yollarının ve taraftar olma sebeplerinin kendi aralarındaki ilişkilerinden kaynaklandığını öne sürmesi bunun bir işareti olarak algılanabilir. En ilginç tespit ise Maienschein (1999)'den gelmiş, araştırmacı bilimsel okuryazarlığın çok farklı anlamlara bürünebilen bulanık bir kelime dizisine dönüştüğünü, insanların gerçekte öyle olmasa bile birbirleriyle uzlaştıkları hissine kapılmasına yol açtığını iddia etmiştir.

Herhangi bir kavram üzerinde uzlaşılması, o kavramın kullanımı ve uygulamalarının geniş bir alanda hayata geçirilebilmesi açısından önemlidir. Buna karşın uzlaşma eksikliğinin o kavramın açılımının daha da zenginleşmesi yolunda bir sürece yol açabileceği veya farklı yorumların farklı bağlamlarda uygulama kolaylığı sağlayabileceği de gözden kaçırılmamalıdır. Bu bağlamda bilimsel okuryazarlığın anlaşılır ve işler bir hedef haline getirilebilmesi için yukarıda ele alınan bakış açılarını da dikkate alarak öncelikle tarihi gelişiminin irdelenmesi, açılımının yapılması ve alt boyutlarının belirlenmesi gerekmektedir. Söz konusu süreç tamamlandıktan sonra ise her araştırmacının kendi perspektifinden ama içinde bulunduğu toplumun ihtiyaçları ve tepkileri doğrultusunda ele alma eğiliminde olduğu bilimsel okuryazarlık, herkes için bir hedef olup olamayacağı noktasında tartışılmalıdır.

\section{Araştırmanın Amacı}

Ülkemiz fen eğitimi literatürü, öğretim yöntem ve teknikleri üzerine kurulu deneysel araştırmaların büyük bir birikim oluşturduğu fakat tarihsel 
gelişim süreçlerini de içeren kuramsal araştırmaların biraz geri planda kaldığı bir yapı sergilemektedir. Özellikle önemli birtakım kavramların, yaklaşımların tarihi gelişim süreçleriyle birlikte ele alınması ve yorumlanması bağlamında yeterli çalışmanın mevcut olduğu söylenemez. Aslında bu durumun ülkemize has değil fakat genel bir sıkıntı olduğunu iddia eden bazı araştırmacıların varlığından da bahsetmek mümkündür. Mesela, fen eğitimi tarihinin anlaşılmasının bugünün olayları için bir perspektif oluşturulmasına önemli katkı sağlayacağını, tarihe dayalı bir perspektif oluşturmanın ise bugünün kararlarını almayı kolaylaştırmasa da aksi takdirde gözden kaçırılabilecek alternatifleri, sonuçları görebilme şansını vereceğini iddia eden Bybee (1982) söz konusu araştırmacılardan sadece birisidir. Bybee (1982), fen eğitimi bağlamında tarihsel araştırmaların çok yetersiz kaldığını, incelediği binlerce tezin, makalenin ancak yüzde ikiden az bir kısmının fen eğitimi tarihiyle ilgili olmasının da bunun bir göstergesi olduğunu kaydetmiştir. Kemp (2000), Bybee (1982)'nin bu tespitinin üzerinde durmuş ve 1982 'den 2000 yılına kadar bu yönde ancak birkaç kitabın yayımlandığını dolayısıyla yazarın iddiasının gerçekçi olduğunu söylemiştir. $\mathrm{Bu}$ yüzden özellikle günümüzün popüler fakat tartışmalı kavramlarının ortaya çıkış süreçlerini ve günümüze değin gelişimlerini ortaya koyabilmek önemlidir. Bu anlayışla bu araştırmada, son yıllarda sıç̧a ön plana çıkmaya başlamış olan bilimsel okuryazarlığın tarihi gelişim sürecinin gözden geçirilmesi, belli dönemlerde hangi düşüncelerle gündeme getirildiğinin belirlenmesi, açılımlarının incelenmesi ve alt boyutlarının tespiti ile birlikte genel eğitim perspektifinde herkes için bir hedef olup olamayacağının tartışılması amaçlanmıştır.

\section{Yöntem}

Bybee (1982), tarihsel araştırmayı önemli fikir, olay, kişi veya kurumların tanımlanması ve temel niteliklerinin ortaya konması süreci olarak tanımlamıştır. Tek başına gerçeklerin çok fazla önem taşımayacağını düşünen Bybee (1982), geçmişin fenomenlerinin içerdiği önemli ilişkileri kurgulayabilmek ve ortaya çıkarabilmek için araştırmacıların ilgili bilgi birikimini analiz etmesi ve yorumlaması gerektiğini ileri sürmüştür. $\mathrm{Bu}$ açılım, önemli ilişkileri ortaya koyabilecek ilgili kaynakları elde etmenin önemine işaret etmektedir ki tarihsel bir araştırma yürütebilmek için Bybee (1982)'nin ön plana çıkardığ 1 ilgililik ve önemlilik kavramlarının 1şığında sistematik bir süreç planlamak hem zaman hem de enerji açısından ciddi kazanımlar sağlayacaktır. Bu anlayışla, bu araştırmada, Bybee (1982)'nin de altını çizdiği ilgililik, önemlilik kavramları ışığında ulaşılan dokümanların incelenebilir bir sayıya indirgenebilmesi için bazı ölçütler belirlenmiş ve araştırma bu ölçütler yardımıyla yürütülmüştür. Belirlenen ölçütler, bilimsel okuryazarlık kavramının veya bileşenlerinin konu başlığı içinde geçmesi, odak kavramlar olarak ele alınmış olması ve fen bilimleri bağlamında 
değerlendirilmiş olması şeklindedir. Bilimsel okuryazarlı̆̆ 1 odak kavram olarak ele alan makaleler içerisinde özellikle DeBoer (2000), Laugksch (2000), Shamos (1995) ve Hurd (1958)'un çalışmaları ciddi anlamda yararlanılan kaynakları oluşturmuştur.

\section{Bilimsel Okuryazarlığın Kısa Tarihçesi}

1950'lerden beri kullanılagelen ve ilk defa o keșfetmemiș olsa da Hurd (1958)'un ele almasıyla birlikte fen eğitiminin önemli temalarından biri haline gelmiş olan bilimsel okuryazarlık kavramı hakkındaki değerlendirmeler 20. yüzyılın başlarından beri gündemdedir. Hurd (1958: 13), teknolojideki uygulamalariyla bilimin modern toplumun en karakteristik özelliklerinden biri haline geldiğini ifade ederek, bilimsel okuryazarlığın önemine dikkat çekmiştir. O dönemlerde Waterman (1960, Akt. Laugksch, 2000: 72)'in fen bilimlerindeki ilerlemenin fen programlarına ve araştırmalarına kamusal destek sağlanmasıyla ve araştırmaların genelde kavranmasıyla ciddi anlamda ilişkili olduğunu ifade ettiği görülmektedir. Böyle bir yaklaşım, 1960'larda, bilimsel okuryazarlık kavramının bilimsel araştırmalara duyulan ilginin artırılması ve bu şekilde kamu desteğinin sağlanması düşüncesiyle ele alındığının önemli bir işaretidir.

Yine o dönemlerde Sovyetler Birliği'nin Sputnik uydusunu dünya yörüngesine yerleştirmesiyle birlikte, ABD'de, fen eğitimcileri bilimsel bilginin toplumdaki stratejik rolü üzerinde daha fazla odaklanmaya başlamıştır. $\mathrm{Bu}$ yoğun ilgiyle birlikte sadece dünya yörüngesine uydular yerleştirildiği veya diğer milletler bilim ve teknoloji çalışmalarına çok önem verdiği için fen bilimlerine odaklanmanın, dolayısıyla fen bilimlerinin eğitim sisteminde başrolü üstlenmesinin sağlıklı bir yaklaşım olmayacağını ifade eden sesler de yükselmiştir. Bilimin uygulamalarıyla dolu bir dünyada yaşandığ 1 ve bilimsel çalışmalarda sonuca ulaşılırken işletilen süreçlerin düşünce sistemleriyle ilgili olduğu, bu yüzden de fen eğitiminin entelektüel katılımın bir parçası olduğu vurgulanmıştır (DeBoer, 2000: 585). Fen bilimlerinin öneminin veya işlevinin değil fakat onu değerli ve işlevsel kılan unsurların ne şekilde yorumlanması gerektiğinin tartışıldığ1 görülmektedir. Aslında bu tartışma bilimsel okuryazarlığın açılımına ve anlamına işaret eden bir süreci de ön plana çıkartmaktadır.

1960'lardan sonra fen eğitiminde iyice belirgin hale gelen yaklaşım akademik disiplinlere olan ilginin artması yönünde olmuştur. Ancak bu disiplinlerin sağlayacağı bilgi birikimi ile ülkenin hem ekonomik hem de askeri olarak güç kazanmasının mümkün olacağı inancı yaygınlaşmaya başlamıştır. Büyük bölümü bilim adamları tarafından hazırlanan yeni fen dersleri programı akademik anlamda çok ciddi ele alınmış ve başarılı öğrencilerin fen bilimlerine yönelmesi için özel bir çaba sarf edilmiştir. Programda, bilimsel uygulamalar veya öğrencilerin günlük yaşantılarına 
hitap eden çalışmalar çok küçük bir bölümü oluşturmuştur. Tercih edilen yaklaşım 19. yüzyıl bilim adamlarının tartıştığı fikrin özgürleştirilmesi değil, araştırma-soruşturma olmuştur. $\mathrm{Bu}$ şekilde bilim adamları, kendi çalışmalarında kullandıkları yola dikkat çekmeyi, yaptıkları işe duyulan saygıyı artırmayı hedeflemiştir. Bilim dünyasının ana hedefi, geleceğin bilim adamlarını ve bilim adamlarının çalışmalarına sempatiyle bakabilecek kadar bilgili bir toplumu yetiştirebilmek olarak görülmüştür (DeBoer, 2000: 587). O dönemlerde bilimsel okuryazarlık teriminin açılımını yapan bazı bilim adamlarının ve fen eğitimcilerinin, ağırlıklı olarak içerik bilgisi üzerinde odaklanması, sadece bir kısmının bilim ve toplum arasındaki ilişkiden bahsetmesi aslında yukarıda çizilen tabloyu daha anlaşılır hale getirmektedir. Mesela Pensilvanya Üniversitesi Jeoloji Bölümü Başkanı Howard Meyerhoff, bilimsel okuryazarlığı, bilimsel metotlara aşina olmak ve yeni buluşlar hakkındaki raporları anlayabilmek için birkaç bilimsel alanda yeterli bilgiye sahip olmak olarak nitelemiştir (Carlton, 1963: 34).

1960'lı yılların daha çok bilimsel araştırmaların anlaşılmasını sağlayacak içerik bilgisi üzerine odaklanmış gündemine karşın 1970’lerde birçok fen eğitimcisinin öğrencilerin ilgileri ve gelişim ihtiyaçları pahasına bilimlerin işleyişine, yapısına odaklanılmasının doğru olmadığını ileri sürmeleriyle birlikte yeni bir tartışma başlamıştır. Bilim ve toplum arasındaki ilişki, bilimin teknolojik uygulamalarıyla birlikte fen eğitimi programlarında yer alması gereken bir olgu olarak yeniden gündeme taşınmıştır. Bu anlamda bilimsel okuryazarlık da bilimin daha geniş bir perspektifini, özellikle de günlük yaşantıyla ilişkisini tanımlayan bir kavram olarak ön plana çıkmıştır. Ulusal Fen Öğretmenleri Birliği’nin (NSTA), bilimsel okuryazar bireyin günlük hayatta, diğer insanlarla ve çevresiyle ilişkilerinde bilimsel kavramları, süreçleri, değerleri kullanabilmesinin ve bilim, teknoloji, toplum arasındaki (toplumun sosyal-ekonomik gelişimi gibi boyutlar da dahil) ilişkiyi anlayabilmesinin gerektiğini öne sürmesi bunun en somut örneğidir (NSTA, 1971: 48).

1970'lerin yukarıda ele alınan hakim anlayışı etkisini ilerleyen yıllarda da devam ettirmiş ve 1970'lerden sonra bilimsel okuryazarlık artık daha çok bilimin sosyal bağlamı içinde tanımlanmaya başlamıştır. Gallagher (1971: 337)'in demokratik toplumlarda geleceğin vatandaşlarının bilimin kavramlarını ve süreçlerini olduğu kadar bilim-teknoloji-toplum ilişkisini de anlayabilmesi gerekeceğini, Hurd (1970, Akt. DeBoer, 2000: 588)'un genel eğitim amaçları için fen öğretiminin en uygun bağlamının ancak bilimin sosyal bağlamı olabileceğini öne sürmeleri bu eğilimin çarpıc1 örneklerindendir. Daha sonra NSTA (1982)'nın “Bilim-Teknoloji-Toplum: 1980'lerin Fen Eğitimi”" çalışması ile fen eğitiminin asıl hedefinin bilimteknoloji-toplum ilişkisinin bilgisine sahip, bu bilgiyi günlük yaşantısında karar alma süreçlerinde kullanabilen bilimsel okuryazar bireyler 
yetiştirilmesi olduğunu ileri sürmesi ise bu eğilimin yakın dönemlere kadar ağırlığını koruduğunu göstermektedir. "Bilim-Teknoloji-Toplum” yaklaşımı taraftarlarının büyük bölümü, bu yaklaşımın en önemli hedefinin sosyal etkinlik-eylem olduğunu ileri sürmüşlerdir. Onlara göre, öğrenciler bilimle ilişkili sosyal konuları tanımlayabilmeli, bu konuların toplumdaki bağlamlarını analiz edebilmeli, bu konuları kendileri araştırabilmeli, karar alma süreçlerinde etkin olan bireyleri-grupları bilmeli, bir eylem planı geliştirebilmeli ve uygun şartlarda bu planı uygulayabilmelidir (Ramsey, 1989: 41-44). Fakat daha önce yüzyılın başlarında William Heard Kilpatrick'in sosyal içerikli problemler içeren "proje metodu"nu ortaya atmasıyla birlikte bir ölçüde gündeme taşınmış olan bu tür bir yaklaşım, daha sonraları önemini kaybetmiş ve fen programları hep öncelikle bilimsel içerik temel alınarak düzenlenmeye devam etmiştir (DeBoer, 2000: 588).

Bilimsel içerik mi yoksa bilimin sosyal bağlamı mı ikileminin gölgesinde 1990'lara gelindiğinde, birçok fen eğitimcisi fen eğitiminde yeniden reforma gidilmesi gerektiği yönünde bir tartışmanın içinde yer almıştır. Fen eğitimi dergilerinde reformdan bahseden makaleler ağırlık kazanmaya bașlamıș ve hatta 1992'de Fen Öğretimi Araștırmaları Dergisi'nin (Journal of Research in Science Teaching) bir sayıs tamamen buna ayrılmıştır. Daha yüksek standartlara ulaşmak, akademik niteliği artırmak ve içerik bilgisini zenginleştirmek başlica hedefler olarak sunulmuştur. Bazı eğitimciler bu yeni standartlara dayalı reform hareketini bilimsel okuryazarlıkla ilişkilendirirken, diğerleri hala "Bilim-TeknolojiToplum" yaklaşımı tipinde bir bilimsel okuryazarlık üzerinde durmuş, içeriğe dayalı olsa bile geliştirilecek programların bilimin sosyal ve kültürel etkilerini de içermesi gerektiğini ifade etmişlerdir. Bu yöndeki tartışmalar sürerken Amerikan Bilimde İlerleme Birliği (American Association for the Advancement of Science, AAAS) 1990'da yayımladığ 1 Proje 2061 kapsamındaki "Bütün Amerikanlar için Fen" ile standartlara dayalı reform hareketi çağrilarına cevap vermek istemiş ve eğitimcilerin bilimsel okuryazarlığı bütün öğrencilerin ulaşabileceği bir konuma getirebilmelerine zemin hazırlamaya çalışmıştır. Reform çalışmaları ABD'nin, bilim ve teknolojinin büyük rol oynadığ 1 bir dünyada, gençliğini diğer ülkeler kadar hızlı bir şekilde çağın gerekleriyle donanımlı hale getirememesi, dolayısıyla açılan aranın kapatılabilmesi için hızla bir şeylerin yapılması gerektiği fikrinden güç almıştır. Bu bağlamda fen eğitiminde reforma gitme sürecinin çok kapsamlı olması gerektiği düşünülmüştür. Öğrencilerin bilimsel okuryazar olabilmeleri için neleri bilmeleri gerektiği noktasında uzlaşmaya gidilmesi, bilimin öneminin herkes tarafindan algılanmas1, yeni ders kitaplarının yazılması, öğretmenlerin belirlenen hedeflere ulaşmalarını sağlayacak niteliklerle donatılması o dönemin gereklilikleri olarak görülmüştür (DeBoer, 2000: 589-590). 
"Bütün Amerikanlar için Fen" yayımlandıktan kısa bir süre sonra Ulusal Bilimler Akademisi (National Academy of Science-NAS) de bütün öğrencilere bilimsel okuryazarlık becerilerinin kazandırılması yolundaki çalışmalara dahil olmuştur. 1992'de başlayan "Ulusal Fen Eğitimi Standartları" çalışması ile ABD hükümeti, eğitim reformuyla birlikte ulusal hedeflerin ve bunlara ulaşılabilmek için de bazı standartların belirlenmesi çabası içine girmiştir. Ulusal standartların amacı, bir dizi içerik standardının yakalanmasıyla birlikte bütün öğrencilerin bilimsel okuryazarlık becerilerine sahip olabilmelerinin sağlanması olarak görülmüştür (NRC, 1996: 1-2). "Ulusal Fen Eğitimi Standartları" geniş katılımlı bir süreçle hazırlanmış ve birçok insanın ortaklaşa yazdığı bir dokümandan bekleneceği gibi uzun yılların birikimiyle belirlenmiş bütün fen eğitimi hedeflerini içermesine dikkat edilmiştir (Collins, 1998: 712).

$\mathrm{Bu}$ tür geniş kapsamlı bilimsel okuryazarlık tanımlamasına en dikkat çekici eleştiri Morris Shamos (1995) tarafından yöneltilmiştir. Shamos (1995), bilimsel okuryazarlık niteliklerine erişebilmek için gösterilen çabayı boş ve kaynak israfı olarak değerlendirmiş, öğrencilerin bilim adamları gibi düşünmeyi öğrenebilecekleri fikrini yersiz bir beklenti olarak görmüştür. Öğrencilerin ilgisini çekebilecek bilimle ilgili sosyal konuların genellikle çok az bilimsel içerik taşıyacağını ve bu tür konularla uğraştıklarında da anlayabileceklerinden çok daha karmaşı durumlarla karşılaşacaklarını öne sürmüştür. Ayrıca bireyleri bilimle alakalı sosyal konularda akılcı, bağımsız karar alma çabası içine sokmanın verimli sonuçlar doğurmayacağını da iddia etmiştir. Ona göre bireylerin bu tür konularda güvenilir uzman önerilerine yönlendirilmesi çok daha sağlıklıdır.

Shamos (1995: 224)'un daha çok üzerinde durduğu şeyin "bilimsel farkındalık" olduğu söylenebilir. Önerdiği fen programında, içerik öncelikli olarak teknolojiye yöneliktir çünkü teknolojinin bilimin soyutlamalarına göre hem daha kullanışlı hem de kavranmasının daha kolay olduğunu öne sürmüştür. Ona göre fen öğretimi bilimin doğasını ve bilimsel süreçleri içermeli fakat tek başına bilimsel içerik çok sınırlı tutulmadır. Shamos (1995: 225)'a göre bilimsel içerik sadece bilimin doğasını ve bilimin ne şekilde işlediğini biraz daha anlaşılır hale getirmek, örneklendirmek için kullanılmalı, programın içeriğgi daha çok doğrudan teknolojinin kendisine odaklanmalıdır. Shamos (1995: 229), okuryazarlı̆̆ın işareti olarak görülen geleneksel bilimsel bilgi üzerinde odaklanılmaya devam edildiği sürece bu tür bir "İşlevsel Bilimsel Okuryazarlığa" ulaşılamayacağını iddia etmiştir. Bilimin doğasını tartışma yolu olmasının dışında bilimsel içeriğe ihtiyaç duyulup duyulmayacağını ele almış olan Shamos'un önerisi, özellikle teknolojinin lehine olacak şekilde bilimsel bilginin öneminin azaltılması ve halkın bilimle ilgili konularda karar alma sorumluluğunun ortadan 
kaldırılması açısından radikal olarak değerlendirilmiştir (DeBoer, 2000: 591).

Bilimsel okuryazarlık kavramının tarihi gelişim sürecinde yer alan tartışmalar, ortaya atılan farklı bakış açıları, bileşenlerinin etüdü vb. günümüzün reform hareketlerinin kavramı ele alış biçimleriyle birlikte değerlendirildiğinde beliren tablo aslında bir dizi belirsizliğin halen bilimsel okuryazarlığa eşlik etmeye devam ettiğini göstermektedir. Yukarıda ele alınan bilimsel içeriğin dozu ve fonksiyonu tartışması bunun en basit örneği olarak sunulabilir. Buna karşın Laugksch (2000)'un bilimsel okuryazarlığın tanımlanma problemi içermeye devam etmesini aslında kavramı oluşturan temel bileşenlerin bir araya getirilme biçimlerinden kaynaklandığ 1 yönündeki görüşü de dikkate alınmalıdır. Laugkch (2000), ilgi grupları, kavramsal açılım, kavramın doğası, taraftar olma sebepleri ve ölçümü şeklinde ele aldığı beş temel bileşenin bilimsel okuryazarlığın yorumlanma sürecinde ele alınış biçimlerinin ve dağılımının eğitimcileri farklı noktalara götürebileceğini iddia etmiştir.

Kavramın gelişiminin tarihçesi bağlamında yapılan değerlendirmeler ve yer verilen görüşler bugün için bilimsel okuryazarlığın basit ve genel kabul görecek bir tanımının yapılmasının çok da mümkün olamayacağını dolayısıyla bir uzlaşma probleminin söz konusu olduğunu göstermektedir. $\mathrm{Bu}$ durum zaman içinde kavramın açılımını daha da zenginleştirecek bir sürece hizmet edebileceği gibi kavramın eğitim programları için işler hale getirilememesine de yol açabilir. $\mathrm{Bu}$ yüzden bilimsel okuryazarlığın kavramsal olarak açılımının ne şekilde yapılmaya çalışıldığına baktıktan sonra en azından söz konusu açılımlarda beliren ortak unsurların, alt boyutların belirlenmesi ve tanımlanması önemli bir gereklilik durumundadır. Zira bilimsel okuryazarlığın alt boyutlarının belirlenmesiyle birlikte eğitim uygulamalarında hangi boyuta nasıl bir ağırlı verilmesi gerektiği de tartışlabilecektir.

\section{Bilimsel Okuryazarlığın Kavramsal Açılımı}

Temelde bilimsel okuryazarlık kültürel öneme sahip bilginin yorumlanabilmesi için gereken süreçlere hâkim olma durumu olarak düşünülebilir. Bunun yanı sıra şu üç husus son yıllarda ciddi olarak dikkat çekmektedir; kabul gören okuryazarlık düzeyi gittikçe artmaktadır, genel nüfus içindeki okuryazar oranı artmaktadır, eğitim-öğretim görmek okuryazar niteliğinin kazanılması anlamına gelmemektedir. Tüm bunlar, bilimsel okuryazarlığın fen eğitiminde önemli bir kavram olarak ortaya atılmasından sonra "Bilim-Teknoloji-Toplum", "Proje 2061" ve son olarak da "Ulusal Fen Eğitimi Standartları (National Science Education Standarts)" gibi birçok çalışmada sıkça telaffuz edilen sözcükler arasında yer almasının nedenini ortaya koymaktadır. Fakat yine de bilimsel okuryazarlık bir kavram 
olarak üzerinde uzlaşmaya varılmış net bir açılıma henüz sahip değildir. Her yeni reform girişiminin farklı bir bilimsel okuryazarlık tanımı geliştirmesi de bunun en somut örneğini oluşturmaktadır. Bu noktada bilimsel okuryazarlık için geliştirilen tanımların bir kısmının araştırmalara, bir kısmının ise bilimsel okuryazar bireylerin özelliklerinin kişisel algılanma biçimlerine dayandığı söylenebilir. İlgili literatür bu iki türün örnekleriyle doludur.

Mesela Pella, O'Hearn ve Gale (1966)'in, Showalter (1974, Akt. Ruba ve Anderson, 1978: 450)'in bilimsel okuryazarlığ tanımlama girişimleri bu ilk türe dâhil olanlara iyi birer örnektirler. Pella, O'Hearn ve Gale (1966), 18 yıllık literatürü tarayarak (1946-1964 arası) dikkatlice seçilmiş 100 makaleyi incelemişler, bu kavramı tanımlamada en çok kullanılan ortak faktörleri belirlemişler ve bilimsel okuryazar olarak nitelenen bir bireyin (1)Bilim ve toplum arasındaki ilişkiyi, etkileşimi, (2)Çalışmalarında bilim adamını yönlendiren ahlaki değerleri, (3)Bilimin doğasını, (4)Bilimin temel kavramlarını, (5)Bilim ve toplum arasındaki farklılıkları, (6)Bilim ve sosyal bilimler arasındaki ilişkiyi, etkileşimi kavrayabilmesi gerektiğini ileri sürmüşlerdir.

Showalter (1974, Akt. Ruba ve Anderson, 1978: 450) ise 15 yıllık ilgili literatürü inceleyerek bilimsel okuryazar olarak tanımlanan bir bireyin (1)Bilimin doğasını anlayabilme, (2)Bilimsel kavramları, prensipleri, kanun ve teorileri günlük hayatta kullanabilme, (3)Bilimsel süreçleri problemlerin çözümünde, karar alma durumlarında ve evreni algılama biçimini geliştirmede işler hale getirebilme, (4)Bilimin altyapısını oluşturan değerlerle tutarlı bir şekilde çevresiyle ilişki geliştirebilme, (5)Bilim ve teknolojinin birbiriyle olan girişimini ve toplumla ilişkisini kavrayabilme, (6)Aldığ 1 fen eğitimi doğrultusunda daha derin, daha tatmin edici bir evren kavrayışı geliştirebilme, (7)Bilim ve teknolojiye dair birtakım becerileri geliştirebilme yeterliklerini göstermesi gerektiğini belirtmiştir.

Bir başka araştırmacı Miller (1983) ise bilimsel okuryazarlığı bugünün penceresinden irdelemiş ve kavramı üç boyutlu düşünmüştür: bilimin metot ve kanunlarının anlaşılması; anahtar bilimsel terim ve kavramların anlaşılması; bilim ve teknolojinin topluma etkisinin anlaşılması. Pella, O'Hearn ve Gale (1966) ile Showalter (1974, Akt. Ruba ve Anderson, 1978: 450)'in yukarıda ele alınan tanımları da aslında yine bu üç temel boyut etrafında gruplandırılabilir. Bu anlamda Miller (1983)'in ele aldığı bu üç boyut birçok tanımı içine alacak şekilde bir çatı oluşturmaktadır.

Turgut (2005) bilimsel okuryazarlığı bireyin modern toplum yaşantısı içinde yetkin biçimde var olabilmesini sağlayacak temel süreçleri kapsayacak şekilde ele almış ve bilimsel okuryazarlığı sürekli bir dağılım halinde düşünmüştür. Turgut (2005)'a göre bilimsel okuryazarlık; "Toplum yaşantısı dâhilinde, şahsiyet geliştirme sürecini tetikleyen en önemli 
unsurlardan biri olarak, bilimin içerik ve doğasını, bilimselliği ve bilimteknoloji-toplum ilişkisini kavrayabilmekten yorumlayabilmeye kadar uzanan kesiti kapsayan bir kavram"dır. Bu tanımlamada bireyin, içinde bulunduğu çağda kendi yaşantısını yönlendirebilecek, toplum yaşantısına katılımda yeterlik gösterebilecek, dolayısıyla "kendini" gerçekleştirebilecek donanıma sahip olabilmesi öngörülmektedir. Bunun için de bireyin bilimi ve teknolojiyi birbirleriyle ve toplum yaşantısıyla ilişkilerini de kapsayacak şekilde kavrayabilmesi gerekli görülmüştür. Bireyin bilimsel okuryazarlığı sürekli bir dağılım halinde düşünülmüş, bilimsel içeriğin ansiklopedik birikim şeklinde ele alınmasının önüne geçilmeye çalışılarak bilimsel içerikle birlikte bilimin doğasına ve bilim-teknoloji-toplum ilişkisine vurgu yapılmıştır.

Bireysel araştırmacıların veya araştırma gruplarının dışında önemli projelerde ve reform hareketlerinde de mutlaka bilimsel okuryazarlığın açılımının yapılmaya çalışıldığı, en azından bilimsel okuryazar olma halinin kıstaslarının belirlenmesinin hedeflendiği görülmektedir. Mesela, Proje 2061 kapsamında bilimsel okuryazarlık, doğal dünyaya aşina olma ve doğal dünyanın birliği fikrine saygı duyma; matematik, teknoloji ve bilimlerin birbirine bağlı olduğu bazı önemli durumların farkında olma; bilimlerin bazı anahtar kavramlarını ve prensiplerini anlayabilme; bilimsel düşünme biçimlerine sahip olabilme olarak ele alınmıştır (Rutherford, Ahlgren, 1990: 10).

"Bilim-Teknoloji-Toplum" yaklaşımı içerisinde bilimsel okuryazarlık, bireylerin, bilim ve teknolojiyi kavramaları, değer vermeleri ve kişisel hayatlarında kullanmaları; bilim ve teknolojinin sosyal konularla ilişkili olabildiğini anlamaları; bilim ve teknolojinin insan çabasının bir ürünü olduğunu görmeleri; demokratik süreçlerde bilim ve teknoloji bağlamında kat1lım göstermeleri olarak düşünülmüştür. (Bybee, DeBoer, 1993: 68). Ulusal Fen Eğitimi Standartları bağlamında ise bilimsel okuryazarlık, kişisel karar alma, toplumsal ve kültürel etkinliklere katılım, ekonomik üretkenlik için gerekli olan bilimsel kavramları ve süreçleri anlayabilme, kavrayabilme olarak görülmüştür (NRC, 1996: 22). (Ulusal Fen Eğitimi Standartları ABD'deki fen öğretimi için bu anlamda ulusal hedefler belirlemiştir).

Ulusal Fen Öğretmenleri Birliği (NSTA) adlı örgüt ise bilimsel okuryazarlık bağlamında ele alınan boyut sayısını biraz daha artırarak bilimsel okuryazarlığı akılcı, meraklı ve kuşkucu olma, bilim ve teknoloji odaklı süreçleri, kavramları vb. kavrayabilme şeklinde tanımlamış, toplam 17 maddelik bir beceriler listesi oluşturmuştur (Yager, 1993: 147-149).

Geliştirilen tanımların ve öngörülen niteliklerin araştırmacıların mümkün olduğunca mükemmeli yakalama gayretlerini yansıttığı görülmektedir. Fakat bu tarz bir mükemmellik arzusu, olabildiğince fazla 
unsuru tanımın içine sokma çabası kavramın hayata geçirilme şansını zaafa uğratmaktadır. Biraz da uygulanabilirliğin ve gerçekçiliğin dikkate alınması gerekmektedir. Bununla birlikte yukarıda ele alınan araştırmacıların ve çalışma gruplarının bilimsel okuryazarlı̆̆ tanımlama biçimleri incelendiğinde, bilimsel okuryazarlığın benzer nitelikler üzerine oturtulmaya çalışıldığı fakat özelde bazı farklılıkların da söz konusu olduğu görülmektedir. $\mathrm{Bu}$ durumda bilimsel okuryazarlığın eğitim programları için işler bir hedef olarak ortaya konabilmesi farklı açılımlarda yer alan benzer niteliklere dayalı bir çatı oluşturulmasıyla mümkün olabilecektir. Yukarıda verilen birçok tanımda bu çatının Miller (1983)'in ortaya koyduğu yapıyla oluşturulabileceği görülmektedir. Zira bilimin doğası, bilim-teknoloji-toplum ilişkisi ve bilimsel içerik bilgisi şeklinde adlandırılabilecek boyutlarının Pella, O'Hearn ve Gale (1966), Showalter (1974, Akt. Ruba, Anderson, 1978: 450) ve Turgut (2005) gibi araştırmacıların, "Bilim-TeknolojiToplum" (Bybee, DeBoer, 1993: 68), Proje 2061 (Rutherford, Ahlgren, 1990: 10) gibi reform çalışmalarının ve NSTA (Yager, 1993: 147-149) gibi kurumların bilimsel okuryazarlık açılımlarında farklı ağırlıklarla da olsa yer bulduğu ortadadır.

Araştırmanın bundan sonraki bölümünde bu üç alt boyut kısaca ele alınmış ve açılımları yapılmış, bu şekilde bilimsel okuryazarlığın bu alt boyutlarıyla eğitim uygulamaları için ne tür bir anlam taşıdığı, hangi bağlamlarda nasıl bir hedef oluşturduğu irdelenmeye çalışılmıştır.

\section{Bilimsel Okuryazarlığın Alt Boyutları}

Bilimsel okuryazarlığın alt boyutlarıyla ele alınması, hem anlaşılırlığının sağlanması ve hangi bağlamlarda ne tür bir hedef olarak anlamlandırılacağının belirlenmesi hem de herkes için bir hedef olarak sunulması durumunda gerekçelerin neler olacağının ortaya konulması açısından önemlidir. Bu anlayışla bu araştırmada, bilimsel okuryazarlık, "bilimsel okuryazarlığın kavramsal açılımı" bölümünde de vurgulandığı gibi üç alt boyutta ele alınmıştır: (1)Bilimin doğası, (2)Bilim-Teknoloji-Toplum ilişkisi, (3)Bilimsel içerik bilgisi.

\section{Bilimin Doğası}

Bilimin doğası, fen eğitiminde bilimsel okuryazarlık kavramının en önemli halkası olma hüviyetiyle giderek daha çok dikkat çekmektedir. Bu eğilim fen öğretmenlerini sadece mevcut bilimsel anlayışla tutarlı bir şekilde öğretime yönelmek yerine, öğrencilere bilimin doğasını kavratma amacını da kazandırmıştır. $\mathrm{Bu}$ anlamda olumlu gelişmelerin kaydedilebilmesi için araştırmacıların bilimin doğasını ele alma biçimlerinin ve üzerinde durdukları bileşenlerin net bir şekilde gözden geçirilmesi gerekmektedir. 
Abd-el-Khalick, Bell ve Lederman (1998), bilimin doğası ile genelde bilimin epistemolojisinin ve bir bilme yolu olarak bilimin veya bilimsel bilginin doğasında var olan değerlerin, inanışların kastedildiğini ileri sürmüşlerdir. $\mathrm{Bu}$ iddiaları, bilimin doğasıyla birlikte bilimsel bilginin doğasında yer alan değerlerin, kabullerin ve zanların da dile getirildiğine işaret etmektedir. Bir başka araştırmacı, Showalter (1974, Akt. Laugksch, 2000: 76-77) ise bilimin doğasını bazı alt başlıklarla ele alarak anlaşılır kılmaya çalışmış ve bu anlamda dokuz farklı boyuttan bahsetmiştir; genel/özel, tarihsel, bütüncül, tekrarlanabilir, deneysel, olası, bir/tek, değişebilir, insani/kültürel.

Duschl (1990: 9), bilimin doğasını iki taraflı olarak tanımlamış, bir tarafta bilimin ürünlerinden, diğer tarafta da bilimin süreçlerinden bahsetmiştir. Bilimin ürünlerini, bilim tarihi boyunca elde edilen bilgi birikimi, gerçekler, prensipler, kavramlar, teoriler ve kanunlar olarak görmüş, tüm bunların bilginin tabanını oluşturduğunu ve bilimin standartlarını belirlediğini öne sürmüştür. Bilimin süreçlerini ise eldeki bilgi birikimini bilimsel girişimlerin bir parçası yapacak metotlar şeklinde düşünmüştür.

Eğitim perspektifinden bakıldığında, artık büyük çoğunluk kabul etmektedir ki bireylerin eğitimi yalnızca bilimsel gerçeklerin, kanunların, teorilerin aktarımı ve bireylerin bunları tekrarı anlamına gelmemektedir. Öğretmenler ve fen eğitimcileri, öğrencilerden, bilimsel bilginin neden değerli olduğunu ve neden ona güvenilmesi gerektiğini anlamalarını da beklemektedir. Bu tavır, fen öğretimine bu anlamda yüklenen bir misyona da işaret etmektedir. Fen öğretimi, "zihinsel bağımsızlı̆̆ı" sağlayan bir değer ve öğrencilere bilginin doğruluğunu başkalarına ihtiyaç duymadan yargılayabilme imkanını verecek kaynakları sağlayan bir süreç olarak tanımlanmaktadır (Munby, 1982: 31).

Böyle bir değerlendirmede, bireyler için, uzmanların tavsiye veya görüşlerine inanıp inanmama durumunun ve bilimle, teknolojiyle ilgili toplumsal sorunlara karşı takınılacak tavrın önemi daha net ortaya çıkmaktadır. Bilimin doğasının toplumsal anlamı demokrasinin ciddi bir bileșeni olarak belirmektedir; bireyler bilim ve teknoloji eksenli konularda karar alma durumunda olacaklardır. Bu yüzden bilimin doğasının öğretim sürecinde yer alması bilimsel okuryazarlığın en önemli hedeflerinden biridir. Bireylerin sağduyulu karar alabilme yetilerinin geliştirilmesi aşamasında bilimsel süreç ve ürünler olumlu etki oluşturacaktır (Carey, Smith, 1993).

Son y1llardaki reform hareketlerinin merkezinde, doğrudan fen bilimleri içeriğinin öğretilmesinden ziyade bilimsel araştırma, buluş süreçleri ile bilimin doğasını da içeren daha geniş, üst düzey temalar üzerinde odaklanma fikri yer almıştır. Bu anlamda epistemolojiyi de içeren bilimin doğasının, 
bilimsel bilginin doğasında yer alan değerlere ve kabullere işaret ettiği düşünülmektedir. Söz konusu değerlerin ve kabullerin öznelliği, değişebilirliği ve yaratıcılığı da bunlarla sınırlı olmamakla birlikte içerdiği söylenebilir.

Bilimsel bilginin özellikleri ve ne şekilde yapılandırıldığı bilindiği zaman yalancı bilimsel (pseudoscientific) iddiaların farkına varılması, doğru olanla yanlış olanın birbirinden ayrıştırılması ve doğru olanın günlük hayatta etkin rol oynamasının sağlanması da kolaylaşacaktır. Bununla birlikte bu özellikler hiçbir zaman genel kabule konu olma durumunda değildir ve bilim felsefecileri, tarihçileri, sosyologları arasında çok çabuk görüş ayrılıkları ortaya çıkabilmektedir. Bilimsel bilgi gibi bilimin doğası da dinamik ve değişkendir. Bu kavramlar bilim ve bilimin doğası hakkındaki sistematik düşünme biçimlerinin gelişimiyle birlikte değişime uğrayacaktır (Lederman, Abd-El-Khalick, Bell ve Schwartz, 2002: 498-499). Mesela artık bilimsel gözlemlerin teorilere bağımlı doğasının reddedilmesi veya bilimin deterministik-mutlak doğasının savunulması çok zordur ve bu tür bir genelleme içinde bilimin doğasının bazı önemli yönleri tartışmalıdır.

Literatür incelendiğinde, bilimin doğası kavramlarından bazılarının hemen her öğretim seviyesi için önemli görüldüğü ve ele alındığı göze çarpmaktadır. Bunlar; değişebilirlik, deneysellik, teorilere bağımlılık, hayal gücü ve yaratıcılık, sosyal ve kültürel değerlere bağımlılık vb. şeklinde sıralanabilir. Tüm bunlara ek olarak gözlem ile çıkarım arasındaki ayrım, tek-evrensel bilimsel metot kabulünün sorgulanmas1, bilimsel teorilerle kanunların ilişkisi ve fonksiyonları da önemli başlıklar olarak görülmektedir. $\mathrm{Bu}$ kavramlar, mevcut fen eğitimi reformu raporlarında da yer almaktadır (Lederman, Abd-El-Khalick, Bell ve Schwartz, 2002: 499).

Yukarıda ele alınan kavramlar, bilimin doğasının daha net anlaşılması ve en azından bilimin ne olup ne olmadığ 1 hakkında bir fikir vermesi açısından önemlidir. Özellikle, birbirine en çok karıştırılan teori-kanun, gözlem-çıkarım gibi kavramlar arası ayrımlar dikkate değerdir. Bilimin doğasına dair birikimin bireylerin günlük yaşantılarına katacağı değer, bu kavramlarla düşünebilmek ve değerlendirmeler yapabilmek olacaktır. Bilgiyi tartma, karar alma süreçlerinde güvenilirliğini sorgulama, sınırlarını ve gücünü betimleyebilme vb. yeterlikler bireylere önemli artı değerler sağlayacaktır.

Bilimin doğasının eğitim programlarında yer almasının gerekliliğini ortaya koyan uygulamalar son yıllarda büyük ivme kazanmıştır. Fakat yine de bazı problemler yok değildir. Mesela Eğitimde İlerleme için Ulusal Değerlendirme (NAEP) adlı kuruluşun hazırladı̆̆ 1 raporda, eğitimcilerin öğrencilerin bilimin gerçek ruhunu anlayabilmelerini sağlayamadığ 1 öne sürülmüş ve milletlerin fen öğretimi için yeterli kaynak ayırmamasının 
bilginin güvenirliğini veya önermelerin mantığını değerlendirebilecek öğrenci kuşaklarının yetiştirilememesine sebep olduğu ileri sürülmüştür (Meichtry, 1992).

Yine de bu konuda yapılan bazı deneysel araştırmaların ortaya koyduğu gerçek, birçok öğrencinin bilimin doğasına dair kavramlarda ciddi yanılgılara düştükleri yönündedir. Bu yanılgıların büyük bölümünün bilimin doğasını yeterli düzeyde yansıtmayan materyallerden ve öğretim uygulamalarından kaynaklandığı düşünülmektedir (Meichtry, 1992). Bilimin doğasının, eğitim programları için gerçekten üzerinde durulması gereken bir olgu olup olmadığının tartışılması aşamasının çok geride kaldığı, ilgili literatürde açık bir şekilde görülmektedir. $\mathrm{O}$ halde artık gelinen noktada yapılması gereken, bilimin doğasının hangi eksende ele alınacağı ve eğitim programlarında nasıl işler hale getirileceğidir.

\section{Bilim-Teknoloji-Toplum İlişkisi}

Bilimsel okuryazarlığın bu başlık altında ele alınan ikinci boyutu; bilimteknoloji-toplum ilişkisi, temelde bilim, teknoloji ve toplum üçgeni içinde gelişen organik ilişkiler bütününü ifade etmektedir. Bilimin teknolojiyle ilişkisi, hangisinin diğerinin gelişimine öncülük ettiği, toplumun teknolojiye tepkisi, toplumun bilimsel araştırma süreçlerine ve sonuçlarına ilgisi vb. birçok olguyu bir arada barındıran bilim-teknoloji-toplum ilişkisi kavramı bu anlamda basit gibi görünen ama aslında karmaşık bir yapıyı anlatmaktadır. Daha anlaşılır hale getirebilmek için bu karmaşık ilişkiyi bazı parçalar halinde düşünmek söz konusu olabilir.

ABD'de yürütülen eğitim reformu çalışmalarından biri olan Proje 2061 ile birlikte hazırlanan "Bütün Amerikanlar için Fen" raporunda da bu yapılmış, bilim-teknoloji-toplum ilişkisi teknolojinin doğası başlığı altında "Teknoloji ve Bilim", "Tasarımlar ve Sistemler" ve "Teknolojinin Önemli Meseleleri” alt başlıklarıyla inceleme konusu yapılmıştır (AAAS, 1990). Bu şekilde teknolojinin ne olduğu, bilimle ilişkisi, teknolojik tasarımların ve sistemlerin doğası, toplum kesimlerinin teknolojinin kullanımına dair tepkileri gibi olgular ayrı ayrı, fakat bir bütünlük içinde ele alınmıştır.

Bilimsel okuryazarlığın bilim-teknoloji-toplum ilişkisi boyutu özellikle gündelik yaşamda ve hatta bazen fen eğitiminde birbirine çok karıştırılan iki kavramı, bilim ve teknolojiyi bir arada barındırması açısından bile önemlidir. Zira teknolojinin uygulamalı bilim olarak görülmesi, bilim ve teknolojinin farklarının net bir şekilde ortaya konulamaması, mühendisi bilim adamından ayıran niteliklerin belirgin olarak ifade edilememesi sıkça karşılaşılan durumlardır (Turgut, 2005). O halde bilimsel okuryazarlığın bu boyutuna eğilirken en azından bu kavramların sağlıklı bir şekilde ele alınabilmesini hedeflemek gerekir. 
Bilim-teknoloji-toplum ilişkisi organik ve çok yönlü bir ilişki olarak görülmelidir. Özellikle sosyolojik bir yönünün de olması nedeniyle bu ilişkiyi yüzeysel olarak tanımlamak hiçbir zaman yeterli olamaz. Fakat fen eğitimi açısından ele alındığında programlarda daha fazla teknoloji eksenli içeriğe yer verilmesi fikri ilk göze çarpan eğilim olmaktadır. Bu şekilde hem teknolojik sistemlerin tasarlanmasına, işleyişine ve toplum yaşantısında gerçekleştirdiği dönüşüme hem de dolaylı bile olsa bu sistemlerin bilimsel altyapısına yani bilimsel içerik bilgisine dikkat çekileceği düşünülmektedir.

\section{Bilimsel İçerik -Terminoloji}

Bilimsel okuryazarlığın bilimsel içerik-terminoloji olarak ele alacağımız üçüncü boyutu bilimsel kavramların, terimlerin bilgisine sahip olma ve bunları anlayabilme, kullanabilme şeklinde düşünülmektedir. Böyle bir boyutun neleri içerdiği ya da ne şekilde tanımlandığı konusunda üzerinde tartışma yapılabilecek çok fazla husus gözükmemektedir. Fen eğitimcileri de en çok bilimsel içerik-terminoloji boyutu üzerinde durmuş ve çalışmalarını ağırlıklı olarak bu alanda yoğunlaştırmıştır. Bu yüzden bu kısımda sadece bilimsel içeriğin belirlenmesi bağlamında farklı bir yaklaşım sergilemiş olan Brossard, Shanahan, Radin ve Lewenstein (2001)'in araştırmasına yer verilmiştir.

Brossard, Shanahan, Radin ve Lewenstein (2001)'in araştırmasında çıkış noktasını bilimsel ve teknolojik terminolojide nelerin bilinmesi gerektiği değil, ABD'de kolektif karar alma süreçlerinde bireylerden beklenen birikim oluşturmuştur. Daha önce yapılmış çalışmaları bu çalışmadan ayıran temel husus budur. Bilimsel okuryazarlığın bir boyutu olarak bilimsel ve teknolojik kelime bilgisini ölçmeye yönelik çalışmalar genel anlamda incelendiğinde, bireylerin bilimsel yapılandırmalarının standart sorularla ve anketler yoluyla değerlendirilmeye çalışıldığg görülmektedir. Öğrencilerin belli alanlardaki bilimsel kavram bilgilerini ölçmeye yönelik çalışmalar ve standart testlerle başarı durumlarının belirlendiği süreçler bu anlayışa örnek olarak verilebilir. $\mathrm{Bu}$ tür değerlendirmelerde insanların uzmanlar tarafından tanımlanmış belli alanlarda ne düzeyde bilgi ortaya koyabildikleri ve geliştirebildikleri üzerine odaklanılmaktadır. Dolayısıyla uzmanların beklentileri ile bireylerin bildikleri ne kadar örtüşürse bireyler o kadar bilimsel okuryazar olarak algılanmaktadır. Laugksch ve Spargo (1996)'nun 'Bütün Amerikanlar için Fen" çalışmasını metodolojik olarak kullanarak geliştirdikleri 110 doğruyanlış cevaplı madde ile bilimsel okuryazarlığın farklı boyutlarını, özellikle de terim bilgisi boyutunu ölçmeye çalışmaları buna örnek olarak gösterilebilir. Oysa değerlendirilmesi gereken terim bilgisine uzmanların karar vermesi, bilimsel kitlenin eğilim ve önyargılarının olmas1 durumunda, okuryazarlığın bütün anlamını etkileyecektir. Bu yüzden böyle bir tartışma ortamı terim bilgisine yönelik ölçme çalışmalarında bireylerden beklenen 
terimlerin seçiminin kim tarafından ve ne şekilde yapılacağ 1 sorusunu gündeme getirmektedir ve problemin merkezinde de bu yer almaktadır.

Brossard, Shanahan, Radin ve Lewenstein (2001), yürüttükleri çalışmada, bu sorunu cevabını alış1lagelmişin dışında vermek istemişler ve kitle iletişim araçlarında düzenli olarak yer alan terimler üzerinden hareketle bilimsel içerik bilgisini ölçmeye yönelik bir araç geliştirmeyi hedeflemişlerdir. Bunun için ilk etapta standart bir bilimsel içerik bilgisi kaynağına “Oxford Bilim Sözlüğü”ne başvurmuşlardır. Bu kaynağın seçilme sebebini biyoloji, fizik, yer bilimleri, astronomi gibi alanlardan 9000 terimi (matematiksel terimler dışarıda bırakılmıştır) ayrıntılı olarak içermesi olarak göstermişlerdir. Daha sonra sistemli örnekleme metodu ile (10 sayının rasgele siras1) her sayfadan bir terimi seçmek suretiyle 896 terime ulaştıklarını ifade etmişlerdir. Bir sonraki aşamada bu terimlerin her birinin Lexis-Nexis veri tabanı üzerinden ulaşılabilinen makalelerde kaç kez geçtiğini tespit etmişler ve kullanılma frekansları bazında bir değerlendirme yaparak en çok kullanılan yüzde 10'luk dilimi oluşturan 72 terimle yeni bir liste oluşturmuşlardır. Son basamakta bu listedeki terimleri boşluk doldurma sorularında kullanılacak cevaplar olarak düzenleyerek bilimsel okuryazarlığın bilimsel içerik bilgisi boyutunu değerlendirmeye yönelik bir araç geliştirme yoluna gitmişlerdir. Söz konusu çalışma "uzman görüşüu" yaklaşımının dışında olması ve olaya başka bir bakış açısı kazandırması açısından incelenmeye değerdir. Bunun dışında genelde uzman görüşüne başvurularak hazırlanmış olan daha birçok ölçme aracından bahsetmek mümkündür. Ayrıca bireylerin kavram bilgilerinin, kavram yanılgılarının, kavram yapılandırma süreçlerinin incelenmesine yönelik araştırmalar da göz önüne alındığında alandaki ilgi ve yoğunluğun derecesi daha rahat anlaşılacaktır.

\section{SONUÇ VE TARTIȘMA}

$\mathrm{Bu}$ araştırmada tarihçesinden başlayarak farklı araştırmacılara göre açılımı ve alt boyutları bağlamında ele alınan bilimsel okuryazarlığın genel eğitim perspektifinde bütün bireyler için ortak bir hedef olup olamayacağının tartışılması amaçlanmıştır. Zira bilimsel okuryazarlığın herkes için ortak bir hedef olup olamayacağının tartışılması eğitim programları içerisinde fen bilimlerinin dolayısıyla fen bilimleri eğitiminin ele alınış biçimini de şekillendirecektir ki bilimsel okuryazarlığın tarihçesi kapsamında ele alınan belli dönemlerde bunun örnekleri görülmektedir. Mesela 1950'lilerde kamunun bilimsel araştırmalara destek sağlamasını temin için ön plana çıkartılan bilimsel okuryazarlık, 1960'larda bilimsel süreçlerde işletilen düşünce sistemlerinin kendi içinde taşıdığı değer açısından önemli olduğu iddiasıyla gündeme taşınmıştır ve dönemin fen eğitimi anlayışını bu yönde etkilemiştir. Daha sonraki dönemlerde ise kavram bilimin sosyal bağlamı $\mathrm{m}$ yoksa akademik bilimsel içerik mi ikileminde şekillenmiş ve yine o 
zamanların fen eğitimi programlarının geliştirilmesinde etkili olmuştur. Günümüzde ise daha çok bireylerin demokratik süreçlere katılabilmeleri için sahip olmaları gereken temel birikim ve beceriler üstüne odaklanıldığı ileri sürülebilir.

Bireylere bir vatandaş olarak yükümlülüklerinin bilincinin kazandırıldığı süreç genel eğitim olarak tanımlandığında bu sürecin bütün öğrenciler için ortak birtakım deneyimleri ve öğrenme durumlarını içermesi gerektiği de öngörülmüş olacaktır. Böyle bir öngörü genel eğitim içerisinde bilimsel okuryazarlığın da bütün bireyler için ortak bir hedef olması gerektiği düşüncesini ön plana çıkaracaktır. Zira en azından toplum yaşantısı içerisinde bireylerin demokratik süreçlere katılabilmesi ve görüş bildirme, karar alma durumlarında kendi iradeleri doğrultusunda eylemde bulunabilmesi için bilimle alakalı sosyal konularda kavrayış yeterliği gösterebilmesi gerekecektir. Örneğin nükleer enerji santrallerinin, küresel ısınmanın vb. tartışıldığı bir ortamda, herhangi bir karar alma sürecinde bireylerin bazı kaynaklara ulaşma, karşıt görüşleri bir arada değerlendirebilme, temel kavramlara hâkim olma gibi yeterliklere sahip olması beklenecektir. Bilim adamlarının görüşlerine kesinlik içeren hükümler şeklinde yaklaşmaktan kaçınıp farklı bağlamların doğruları fikrine açık olabilmek de bu yeterliklere eklenebilir. Bu tür bir yaklaşım fen bilimlerinin sosyal bağlamlar içerisinde ele alınması, toplumla ve teknolojiyle organik bir ilişki içinde görülmesi gibi eğilimleri de besleyecektir. Hurd (1970, Akt. DeBoer, 2000: 588)'un genel eğitimin amaçları doğrultusunda fen öğretiminin en uygun bağlamının ancak bilimin sosyal bağlamı olduğunu iddia etmesi de bunu göstermektedir.

Yukarıda ele alınan görüşlerle birlikte bilimsel okuryazarlığın bireylerin bilimin, teknolojinin işleyişini ve toplumla ilişkilerini ana hatlarıyla kavrayabilmesi olarak düşünülmesi durumunda gerek genel eğitim kapsamında gerekse fen bilimleri eğitimi kapsamında bütün bireylere dönük bir hedef olması gerektiği daha rahat anlamlandırılabilecektir. Hedefin bütün bireyler olabilmesi için dikkat edilmesi gereken ise bilimsel okuryazarlığın üzerine kurulacağı fen bilimleri algısının ve motivasyonun şekillendirilme biçimidir. Hurd (1958: 14)'un teknik donanıma sahip işgücü ihtiyacı ne kadar önemli ise, bütün öğrencilerde kültürel bir güç olan bilime karşı takdir duygularının geliştirilebilmesi de aynı oranda önemlidir tezi bu doğrultuda düşünülmelidir. Yine Hurd (1958: 15-16)'un fen eğitimcilerinin, bilimsel buluşun ruhunu işleyen, bilimi bir keşfetme süreci ve entelektüel bir başarı olarak takdim eden, bilime karşı takdir duygularını geliştirecek öğrenme deneyimlerini seçmekle yükümlü olduklarını anlatan ifadeleri de bu görüşü desteklemektedir.

Bilimsel okuryazarlığın neden herkes için bir hedef olması gerektiğine dair bazı ipuçları aslında fen eğitimi üzerine yoğunlaşmış önemli kurumların 
söylemlerinde de görülmektedir. Mesela NSTA (1982)'nın fen eğitiminin as1 hedefinin bilimin, teknolojinin ve toplumun birbirlerini nas1l etkilediğinin bilgisine sahip, bu bilgiyi günlük yaşantısında karar alma süreçlerinde kullanabilen bilimsel okuryazar bireyler yetiştirilmesi olduğu yönündeki açılımı bilimsel okuryazarlığın herkes için bir hedef olarak görüldüğünün göstergesidir. Amerikan Bilimde İlerleme Birliği'nin yayımladığı Proje 2061 kapsamındaki "Bütün Amerikanlar için Fen" ile fen eğitiminin hedeflerinin netleştirilmesi ve eğitimcilerin bilimsel okuryazarlığ bütün öğrencilerin ulaşabileceği bir konuma getirebilmelerine zemin hazırlanmasının amaçlanması da yine bu yönde yorumlanabilir (AAAS, 1990). ABD'de birtakım ulusal standartların belirlenmesiyle birlikte bütün öğrencilerin bilimsel okuryazarlı becerilerine sahip olabilmelerinin sağlanmasının hedeflenmesi ise bir başka örnektir (NRC, 1996).

Diğer yandan bilimsel okuryazarlığın özellikle çok geniş kapsamlı tanımlanmaya çalışılmasına ve nitelikler anlamında uzun listelerin oluşturulmasına karşı tepkilerin de olduğunu kaydetmek gerekir. Örneğin Shamos (1995), bilimsel okuryazarlık niteliklerine erişebilmek için gösterilen çabayı boş ve kaynak israfı olarak değerlendirmiş, öğrencilerin bilim adamları gibi düşünmeyi öğrenebileceklerini tasavvur etmeyi yersiz bir beklenti olarak görmüștür. Shamos (1995)'un herkes için bilimsel okuryazarlık düșüncesini gerçekçilikten uzak bir hayal olarak gördüğü ortadadır. Fakat burada dikkatler bilimsel okuryazarlığın anlaşılma biçimine ve hedeflenen düzeye odaklanmalıdır. Zira Shamos (1995)'un ve benzer görüşte olanların temel dayanağı bireylerin bilim adamları gibi yeterlik geliştiremeyeceğidir ki haklıdırlar. Oysa bireylerden beklenen, Turgut (2005)'un da ifade ettiği gibi, en azından temel düzeyde birtakım yeterliklerin sergilenebilmesi olursa bilimsel okuryazarlığın herkes için bir hedef olarak görülmesi gerçekçiliğin sınırlarında kalacaktır. Dolayısıyla bilimsel okuryazarlığı yukarıda ele alındığı gibi sadece fen bilimleri eğitimi alanlar için değil genel eğitim kapsamında herkes için bir hedef olarak sunarken belirlenen yeterliklerin, yapılan tanımlamaların gerçekçilikten uzak olmamasına dikkat edilmelidir.

Bilimsel okuryazarlığa belli dönemlerde neden taraftar olunduğuna dair tespitler ve yorumlar da göstermektedir ki, bilimsel okuryazarlık bundan sonraki dönemlerde de (ister ülkelerin ekonomik kaygıları ve hızla gelişen teknolojiye ayak uydurma çabaları isterse fen bilimlerinin kendi içinde taşı1’ğg değere duyulan saygı nedeniyle olsun) eğitim programlarının odak kavramı olmaya devam edecektir. Son dönemlerde ülkemizde yürütülen program geliştirme çalışmalarında ve özellikle yeni ilköğretim fen ve teknoloji programında da bu açıkça görülmektedir. Zorunlu olan ilköğretim kademesinde yer alan yeni fen ve teknoloji programında odak kavramlardan biri olarak sunulan bilimsel okuryazarlığın artık herkes için bir hedef olarak görüldüğü ortadadır. 


\section{KAYNAKLAR}

Abd-El-Khalick, F., Bell, R. L. \& Lederman, N. G. (1998). The Nature of Science and Instructional Practice: Making the Unnatural Natural. Science Education, 82, 417-436.

AAAS [American Association For The Advancement of Science] (1990). Science For All Americans. Newyork, Oxford: Oxford University Press.

Brossard, D., Shanahan, J., Radin, J. \& Lewenstein, B. (2001). "Scientific Literacy: Scientific and Technical Vocabularies in Media Coverage." Paper Presented in 6th International Conference on Public Communication of Science, Technology, Geneva.

Bybee, R. W. (1982). Historical Research in Science Education. Journal of Research in Science Teaching, 19(1), 1-13.

Bybee, R. W. \& Deboer, G. (1993). Goals for the Science Curriculum. In Handbook of Research on Science Teaching and Learning. Washington DC: National Science Teachers Association.

Bybee, R. W. (1997). Achieving Scientific Literacy: From Purposes to Practises. Portsmouth, NH: Heinemann.

Carey, S. \& Smith, C. (1993). On Understanding The Nature of Scientific Knowledge. Educational Psychologist, 28, 235-251.

Carlton, R. (1963). On Scientific Literacy. NEA Journal, 52(4), 33-35.

Collins, A. (1998). National Science Education Standarts: A Political Document. Journal Of Research in Science Teaching, 35(7), 711-727.

DeBoer, G. E. (1991). A History of Ideas in Science Education: Implications for Practice. New York: Teachers College Press.

DeBoer, G. E. (2000). Scientific Literacy: Another Look at its Historical and Contemporary Meanings and its Relationships to Science Education Reform. Journal of Research in Science Teaching, 37(6), 583-599.

Duschl, R. A. (1990). Restructuring Science Education. New York: Teachers College Press.

Fleming, R. (1986). Adolescent Reasoning in Socio-Scientific İssues, Part I: Social Cognition. Journal of Research in Science Teaching, 23, 689698.

Gallagher, J. (1971). A Broader Base for Science Teaching. Science Education, 55, 329-338.

Hurd, P. (1958). Science Literacy: Its Meaning for American Schools. Educational Leadership, 16, 13-16. 
Kemp, A. C. (2000). "Scientific Literacy for All: Rationales and Realities." Paper Presented at the Annual Meeting of the American Research Education Association, New Orleans, LA.

Laugksch, R. C. (2000). Scientific Literacy: A Conceptual Overview. Science Education, 84(1), 71-94.

Laugksch, R. C. \& Spargo, P. E. (1996). Construction of a Paper and Pencil Test of Basic Scientific Literacy Based on Selected Literacy Goals Recommended by The American Association for the Advancement of Science. Public Understanding of Science, 5(4), 331-359.

Lederman, N. G., Abd-El-Khalick, F., Bell, R. \& Schwartz, R. (2002). Views of Nature of Science Questionnaire: Toward Valid and Meaningful Assessment of Learners' Conceptions of Nature of Science. Journal of Research in Science Teaching, 39(6), 497-521.

Mainschein, J. (1999). Commentary: To the Future-Arguments for Scientific Literacy. Science Communication. 21(1), 75-87.

Matthews, M. R. (1994). Science Teaching: The Role of History and Philosophy of Science. New York: Routledge.

Meichtry, Y. J. (1992). The Impact of Science Curricula on Students Views about the Nature of Science. Journal of Research in Science Teaching, 30(5), 429-443.

Miller, J. D. (1983). Scientific Literacy: A Conceptual and Empirical Review. Daedalus, 112(2), 29-48.

Munby, H. (1982). "What Is Scientific Thinking?" A Discussion Paper, Ottawa: Science Council of Canada.

NRC [National Research Council] (1996). National Science Education Standarts. Washington, DC: National Academy Press.

NSTA [National Science Teachers Association] (1971). NSTA Position Statement on School Science Education for 1970's. The Science Teacher, 38, 46-51.

NSTA [National Science Teachers Association] (1982). ScienceTechnology-Society: Science Education for the 1980s. Washington DC: Author.

Pella, M. O., O’Hearn, G. T. \& Gale, C. G. (1966). Referents to Scientific Literacy. Journal of Research in Science Teaching, 4, 199-208.

Ramsey, J. (1989). A Curriculum Framework for Community-Based STS Issue Instruction. Education and Urban Society: Issues-Based Education, 22(1), 40-53. 
Ruba, P.A. \& Anderson, H. O. (1978). Development of an Instrument to Assess Secondary School Students' Understanding of the Nature of Scientific Knowledge. Science Education, 62(4), 449-458.

Rutherford, F.J. \& Ahlgren, A. (1990). Science for All Americans. New York: Oxford University Press.

Shamos, M. (1995). The Myth of Scientific Literacy. New Brunswick, NJ: Rutgers University Press.

Turgut, H. (2005). "Yapılandırmacı Tasarım Uygulamasının Fen bilgisi Öğretmen Adaylarının Bilimsel Okuryazarlık Yeterliklerinden Bilimin Doğası ve Bilim-Teknoloji-Toplum İlişkisi Boyutlarının Gelişimine Etkisi.” Yayımlanmamış doktora tezi, Yıldız Teknik Üniversitesi Sosyal Bilimler Enstitüsü, İstanbul.

Yager, R. E. (1993). Science-Technology-Society as Reform. School Science and Mathematics, 93(3), 145-151. 